\title{
Free education as superstructure: Phenomenological study of free private education
}

\section{Pendidikan gratis sebagai suprastruktur: Studi fenomemologi tentang pendidikan privat gratis}

\author{
Marhaeni Mega Wijayanti, Tuti Budirahayu, \& Novri Susan \\ Department of Sociology, Faculty of Social and Political Sciences, Universitas Airlangga \\ Address: Jalan Dharmawangsa Dalam, Surabaya, East Java 60286 \\ E-mail: marhaeni.mega.wijayanti-2017@fisip.unair.ac.id, tuti.budirahayu@fisip.unair.ac.id, \\ \& novri.susan@fisip.unair.ac.id
}

\begin{abstract}
As a manifestation of functionalism, free education becomes a way to eradicate economic disparity by opening access to school for all people. This method is standard in many developing countries as it could foster development. However, the most fundamental problem of this disparity, oppression, and class domination are understudied. To make things worse, studies that do discuss these topics suffer from class bias conceptualization of free education. Therefore, this study aims to demonstrate how free education takes part in a capitalistic society as a superstructure through the correspondence thesis. Subsequently, this study identifies essential elements in (capitalistic) free education. Phenomenological-based qualitative method is used to describe experiences of 21 informants in Selamat Pagi Indonesia (SPI) Senior High School. Data gathered from observation, interview, and secondary sources, and then analyzed phenomenologically. We found that free education, instead of bringing people to equality and freedom from disparity, entraps students deep into modern capitalism through 1) normalization to serve, and 2) giving up power to the capitalist. This condition would benefit many corporations from taking part in aiding the school foundation and perpetuate the domination of the bourgeoisie over the working class. Thus, this study suggests that the capitalistic feature of free education is disrupting its conventional conceptualization.
\end{abstract}

Keywords: free education; concept; correspondence thesis; capitalism; school

\begin{abstract}
Abstrak
Sebagai manifestasi dari pandangan fungsionalis, pendidikan gratis menjadi cara untuk mengatasi kesenjangan ekonomi melalui penyetaraan kesempatan bersekolah. Cara itu umum di negara berkembang sebagaimana ia dapat mempercepat pembangunan, namun masalah yang lebih mendasar dari kesenjangan ekonomi yaitu penindasan dan dominasi kelas, dan oleh karenanya konseptualisasi pendidikan gratis mengalami bias kelas. Studi ini mendemonstrasikan pendidikan gratis sebagai suprastruktur kapitalisme melalui tesis korespondensi lalu mengidentifikasi elemen-elemen pentingnya untuk menemukan ciri pendidikan gratis di masyarakat kapitalisme. Metode kualitatif berpendekatan fenomenologi digunakan untuk mendeskripsikan pengalamanpengalaman 21 informan di Sekolah Menengah Atas Selamat Pagi Indonesia (SMA SPI). Data dikumpulkan dengan metode observasi, interview, dan penelusuran data sekunder kemudian dianalisis berdasarkan kepada kerangka konseptual marxis. Studi ini menemukan bahwa pendidikan gratis, alih-alih memperjuangkan keadilan, justru semakin menjebak siswa ke dalam kapitalisme modern melalui 1) penormalisasian untuk melayani, dan 2) memberikan kuasa kepada para pemilik modal. Kondisi ini menguntungkan banyak korporasi yang membantu pendanaan Yayasan SMA itu dan melanggengkan dominasi borjuis terhadap kelas pekerja. Artikel ini kemudian menawarkan karakteristik kapitalisme dalam pendidikan gratis untuk mendisrupsi konseptualisasi konvensional pendidikan gratis.
\end{abstract}

Kata kunci: pendidikan gratis; konsep; tesis koresponden; kapitalisme; sekolah

\section{Introduction}

Free education for the poor is a moral as well as a constitutional obligation. The 1945 Constitution Article 31 guarantees the rights (verse 1) of every citizen to free primary education and obliges the state to finance this education (verse 2). Free education is also in line with the commitment among 
developing countries, which is stated explicitly in MDGs, and later SDGs, as Education for All (EFA) (UNESCO et al. 2015). Therefore, Indonesia strives for providing access and opportunities to its citizens from all class and gender to participate in primary education through the free education scheme.

Equalization of opportunity and quality of education is theoretically rooted in Durkheimian and Parsonian functionalism. In this perspective, education has an interdependent relationship with other institutions and is an essential factor in development. School Participation Rates (APS), thus, are essential for human capital, health, and the economy. The free school program provides investment for Indonesia because the growing APS will increase economic opportunity and better resilience to economic and political crises (Assaad \& Krafft 2015, Xiao et al. 2017). The increase in APS occurs among elementary school-age children (Ministry of National Planning and Development \& UNICEF 2017). If this number also increases for the following education levels, Indonesia will experience higher economic growth beyond the prior years.

The effectiveness of free education programs, according to several reports, varies. In China, free education is very beneficial for development because it is positively related to school graduation, cognitive improvement, and health (Xiao et al. 2017) in the long run. Other studies also report the same effect when reviewed in the short term (Chyi \& Zhou 2014, Shi 2016). Nonetheless, different studies come up with contradictory results: that free education initiated by the state is a myth, or that free education is not really 'free' because it is dependent on the socio-economic background of students (Assaad \& Krafft 2015, Lincove 2009, Urwick 2011). Free education in India does increase the APS, but families still have to prepare for expenses related to education, centred on substantial matters for student graduation (Bhattacharya 2012). Such expenditures may be substantial for lowerclass families, so the opportunity to receive primary education is not truly universal. These differences in findings are due to differences in implementation. While China covers all education costs, many other countries only cover school fees.

The critical issue to review is not only the problem of its implementation but the socio-historical oppression that persists in capitalist society. Most studies on free education contain class biases, ignoring the undergoing class conflicts in modern society. They consider inequality as the most critical issue so that the problem of injustice arising from the dominant class ideology ignored. Free education, in such a view, is assumed to only deal with efforts to increase the APS.

The transformative approach is the appropriate lens for reviewing the roots of oppression in education (Datzberger 2018). In this regard, development, rather than being understood as a solution, is criticized. Based on the thinking of critical scholars such as Paulo Freire, education is not only fought for the fulfilment of fundamental human rights, but also liberation from social, economic, and political oppression. Justice, therefore, is not only about equal access to education but also about internalizing efforts to transform lives with the assumption that society is influenced socially and historically (Franks 2019).

This study focuses on class relation by employing a Marxian perspective to identify class oppression that has been ignored by many researchers in free education studies. Consistent with the correspondence thesis, this research posits free schools as part of capitalism. Next, elements of class oppression in free education are exposed to disentangle conventional definitions of free education. These elements, as will be discussed later, are traced through the phenomenology of free schools in Indonesian capitalism society.

In developing countries, such as Indonesia, free education is part of the government's efforts to enhance national development. Economic growth, an essential feature in developmentalism, depends on the quality of education that provides a particular quality workforce. Participation in education is essential in running the economy (Earle et al. 2018). Also, there is a Universal Declaration of Human Rights (UDHR) which constructs education as a universal moral right. Free education programs for the public are a part of the development strategy and at the same time in conformity with the country's moral values. 
Studies show that the effectiveness of funding assistance for the social sector varies. In the education sector, much financial assistance not delivered through the right channels (i.e. beneficiaries). Even so, D'Aiglepierre \& Wagner (2013) argues that the allocation of funds is significant because it significantly increases the APS and gender equality. Access to education levels, graduation rates, participation in primary education, and participation based on gender are positively related to increasing primary education assistance fund. Moreover, free education has been proven to increase social equality in a society based on fundamental human rights (Lucas \& Mbiti 2012, Nkurunziza et al. 2012).

Another studies, on the contrary, shows the injustices that continue to persist along with the ongoing free education programs. In the case of Egypt, although the Egyptian government has increased free education to improve APS, it has not achieved the success of putting children in school because it depends on the socio-economic conditions of agriculture (Assaad \& Krafft 2015). Families still have to deal with expenses incurred from the supposed free education. Such expenses include complimentary learning and private lessons, which are common in developing countries (Article 33 Indonesia 2016, Bhattacharya 2012, Supriyadi 2010). Private tutorials or homeschooling can be used by teachers to get incentives by transferring learning material to the privatization of learning. Besides, the increase in APS does not determine the quality of higher education. Improvement is important (Lesoli et al. 2014, Muyanga et al. 2010, Urwick 2011). Thus, there is an urgency to reformulate the concept of free education beyond its conventional understanding, which ignores the context of capitalist society.

Social institutions, including education, reflect the social infrastructure: the economy. Based on dialectical and historical materialism concept, the thesis considers that the basis of the superstructure determined by the structure of the economy (Tucker 1978). Bowles \& Gintis (1976), consistent with Marx's teachings, argue that education serves the interests of the dominant class, namely capitalist economic activity whereas the oppressed class experiences a false awareness that they participate equally with the oppressor class through the discourse of hard working.

Students, in this thesis, are not so much different from workers; they are interested in rewards in their school class/educational degree. They alienated from their productive activities in school. School organization is devoted to disciplining students to accept work patterns in large companies (Labaree \& Cole 2006). At present, synchronization between education and workplace is a topic discussed by students and teachers in Indonesia without drawing much criticism. The school-to-work flow is a generally accepted way of thinking and will be very strange when it comes to transformative thinking. It is consistent with Bowles and Gintis' argument that schools shape the personality of workers in their students - even though they do not have the theory of personality formation. So, instead of equalization, social justice, and rights, educational institutions play a role in defending injustice by internalizing their students to accept the production relations that they will encounter later in the society - that are the servants for the capitalists. However, several criticisms rise against Bowles and Gintis because of their neglect of cultural elements and student-teacher ability to resist (Ball 2012, Harris 1994, Willis 1981).

The most massive development in Indonesia occurred during the Soeharto era, a period in which hegemony was dominant. Such an ideology of development continues today. It concludes, therefore, that Indonesian society is a capitalist one. Following the correspondence thesis, the features of capitalism in free education can explore in the Indonesian context. This study examines free schools that are funded by private parties, namely Selamat Pagi Indonesia (SPI) Senior High School. Locus of this research differs from most studies that mostly examine free education from public schools perspective. A business entrepreneur primarily funds this school. Even though the state questions it because of its implementation of different curriculum, which will be discussed later, the school continues to operate.

\section{Research Method}

This study uses qualitative research methods with a phenomenological approach to understanding learning experiences in free schools in capitalist society. Phenomenological research is descriptive 
research that focuses on the structure of experience, which gives shape and meaning to the world (Osborne 1994). Phenomenology was chosen because it explores the essential features of a phenomenon by describing subjective experiences. The phenomenological approach gives advantages in this study because most free education studies use quantitative methods which ignore the richness of experience and meaning that lives on students and schools (Gill 2014).

Capitalist society is composed of a superstructure that supports infrastructure, or infrastructure that forms a superstructure. This study, following the correspondence thesis, does not distinguish between state, private, and community as parties which carry out free education because schools are a superstructure (Bowles \& Gintis 1976, Labaree \& Cole 2006). This research, therefore, makes SPI High School as a locus of research, in contrast to most studies examining public schools. Informants traced through the snowballing method. There were 21 informnats in this study, consisting of all SPI High School stakeholders, namely the principals, school expert staff, students, alumni, teachers, security guards, janitors, school business managers, as well as school administrators.

Data collected from observations, in-depth interviews, and secondary sources. Interviews were conducted to capture informants' direct experience descriptions about free education at SPI High School. Observations and secondary data collection is conducted to confirm and complete the experience that might not be conveyed during the interviews. Transcripts were made to manage the data and mainly to focus on the study. Then, the entire transcripts were read repeatedly to get a comprehensive understanding of the phenomenon. Meanings that were not relevant to the phenomenon studied were then sorted out. The focus was given to the themes that emerge from every free education experience based on the interests of the researcher, namely the focus that is relevant to the correspondence thesis. Interrelated meanings were then synthesized to be transformed into consistent statements to express the structure of free education.

\section{Results and discussion}

\section{False resistance: Moral goodness based on false consciousness}

SPI High School was established to help lower-class children (e.g. street children), so they can continue their education. Selection is carried out on prospective students with the main requirements being: coming from low-income families, having a single parent, or being orphans from various cultural backgrounds in Indonesia. Itis in line with the mission of the school, which not only carries the concept of free education but also emphasizes the value of multiculturalism. SPI High School does not only offer free education but also provides boarding school facilities so that learning can be more effectively integrated. Besides, students are also given a monthly allowance of IDR 150,000 to IDR 200,000 to meet their urgent needs.

The idea for the establishment of this school came from an MLM (Multi-Level Marketing) business entrepreneur, Julianto Eka Putra. At first, he felt empathy for the many street children who could not continue schooling. Then he felt the calling to establish a free education institution for orphans and underprivileged children. By utilizing a network of colleagues throughout Indonesia, this dream came true in 2010. The funding of this school is borne entirely by the foundation so that parents do not need pay fees.

“... before the 2000 meeting, he often saw children at road junctions. Children who were still at school age, singing songs to drivers and doing various works to make a living. He wanted to give solutions for the betterment of the lives of such children, giving them free education rather than letting them live on the streets..." (RSN, Principal of SPI High School)

Society in capitalism suffers from a false consciousness (Kalekin-Fishman 2008, Marx 1932): a condition of being unable to realize class oppression carried out by the dominant class. This common disease causes the oppressed class to accept and maintain existing injustice. The support for free education is rooted in false public awareness, which thinks that the issue of education is solely about 
participation and educational facilities. Providing free education, then, is seen as a moral obligation. The founder of SPI High School, therefore, also suffered from false consciousness. Its founder saw the issue of contemporary education solely in terms of limited access to education. It reflects his view of schools as a functional part of society. This view is also consistent with those who support conventional free education. As a result of having embodied values which appropriate the oppression by the dominant class (Kalekin-Fishman 2008) and disrupt cognitive-critical capacity (Thompson 2015), the solution offered was not to threaten class domination but to maintain that domination.

The emphasis on individual efforts to climb up the economic class is a manifestation of maintaining class dominance - that is, by focusing students' attention on individual problems rather than economic class problems. Attention to individual abilities is an ideology that legitimizes class domination in society (Bowles \& Gintis 1976). Furthermore, SPI High School organizes students to practice school business affairs and provides special housing for students. It is consistent with the argument of Bowles \& Gintis (1976) that the school is a place to produce worker. How students organized in SPI High School makes it easy to normalize workers' values, because practices can be controlled, monitored, assessed, and responded to without intervention from outside.

Emotional preferences of the school, which packaged as a form of moral goodness (empathy), is not a struggle against real injustice. As a result of false consciousness, resistance to limited access to education through the establishment of free schools is a fake one (false resistance). Instead of striving for justice, schools produce blue-collared and white-collared workers (Bowles \& Gintis 1976).

\section{Foundation-based funding as a form of school dependence on the bourgeoisie and learning classes}

The establishment of SPI High School is part of corporate social responsibility (CSR) of PT. High Dessert Indonesia (HDI) in the field of education. Initially, the company did not have sufficient funds to establish a free school. Then the company sought to raise funds from distributors to run this CSR program. The program financed $50 \%$ of the company's profit and another 50\% from the distributors of PT. HDI, which then used to cover school operational costs as well as student living costs. CSR for companies has a vital role in increasing the attractiveness to stakeholders, which in terms of PT. HDI, the school, builds economic relations with capital owners (Handjaja 2013). Along with the rapid development of SPI High School, several stakeholders who engage continue to increase from year to year. The stakeholders include 1) PT. Bridge Indonesia; 2) Surabaya Voice Radio; 3 ) M Radio Surabaya; 4) Bandar Djakarta Restaurant Surabaya; 5) MIC Publishing Surabaya; 6) Best Investment Choice; 7) Billionaires; 8) PT. MIC Transformer, and 9) PT. Hooray Indonesia.

In addition to relying on funding from external parties, SPI High School also has another source of income from Kampoeng Kidz. The establishment of this village-based tourism aims to employ alumni as well as entrepreneurial learning media for students at SPI High School. Through the involvement of alumni and students in the business, it expected that school operational costs and living allowance for students could be met. In this case, all social relations that are built are economic relations which target is the production of labour. It is following the arguments of Bowles and Gintis (1976). Also, learning through business, as explained previously, internalizes and adapts students to the workforce system and its hierarchy, as well as the interpersonal structure of that hierarchy (Bowles \& Gintis 1976).

Another strategy employed by the school to cover operational costs through Kampoeng Kidz is by setting sales targets for each division. Each division can help each other so that targets can be achieved. This target establishment aims to practice entrepreneurship skills of each student. Students who successfully reach the target will get various rewards such as good grades, high salaries, and/or overseas holiday trips.

\footnotetext{
"So when I was part of the team YES, my records during school affected the salary. Those who had outstanding learning performance gain salary compared to the rest. If they only work in one division, they only get a salary from a single source. However, if they participate in several divisions, they would gain more salary.” (IF, SPI High School Marketing Division)
} 
In the initial period of establishment, SPI High School experienced various obstacles in terms of licensing, financing, and maintaining the commitment of its stakeholders. Solutions of the owner foundation took the initiative to establish a business that was able to be carried out by the educational institution. Hence, they launch a food product called Choco Banana (banana chips mixed with chocolate). With the food business gaining a good response, the school sought to develop other businesses in the field of educational tourism. Kampoeng Kidz, then, was established. This business engages in various sectors such as hospitality, tour and travel, agriculture, and education (outbound activities for school-aged children).

Kampoeng Kidz business began to open in January 2010. The purpose of opening this village-based tourism are: 1) to instil entrepreneurial spirit early on, 2) to teach the visitors of Kampoeng Kidz to appreciate any earning from what they do, and 3) to invite visitors to experience the atmosphere of rural life through various activities such as: outbound, planting and harvesting, feeding pigeons and rabbits, and various other knowledge about livestock. Aside from a learning facility, Kampoeng Kidz is also often used by companies, schools, institutions, and communities for internal meetings. With the development of "Kampoeng Kidz", the school increasingly involves alumni and students to help to manage the business professionally.

The practice of involving students in business activities forms social values that are precisely similar to the incorporation of the one. It is in line with the argument of Bowles \& Gintis (1976) that school management corresponds with the hierarchical and impersonal structures of modern factories and corporations. The school, then, initiates students to enter the workforce and reproduces the division of labour based on the subordination and superordination of the economic position they will receive.

\section{Curriculum and normalization of workers}

SPI High School has three compulsory curricula that students must go through during the learning process. The curriculum includes the Ministry of Education and Culture curriculum, life skills curriculum, and the PAKSA curriculum. The life skill curriculum is one of SPI High School programs that aims to explore the potential of students to be better prepared to compete in the workforce. The process of drawing out student's potential is done through SEL (Student Experience Learning) based teaching material. Through these teaching materials, students are required to choose one division according to their respective talents. After knowing their talents, students can display their talents in the SPI Got Talent activities. The results of this activity will be assessed by the division head to place the students in the right division. The divisions provided by SPI High School include shows, programs, purchasing, animal farms, restaurants, merchandise, hydroponics, and marketing.

"So every child who attends here has to participate in SPI Got Talent. They show what they can do. It is not what they like, but what they can. I, for example, can cook; or I can dance; I can sing; I can draw; things like that." (CHK, YES SPI)

After dividing students into several divisions, the alumni monitors their progress within a specific time frame. If students can develop their talents well, they will be placed in the same division or can choose to move to another division. Conversely, if they do not show significant progress, they will be transferred to a more suitable division. This division transfer aims to develop the potential of the students, so they have sufficient skills to open a business after graduating from SPI High School.

In addition to implementing the life skill curriculum, SPI High School also applies the PAKSA curriculum. The instruments used in this curriculum include Prayer, Attitude, Knowledge, Skill, and Action. These instruments serve as the school's benchmarks in providing educational value and student allowances. Through these instruments, the school strive to hone soft skills, develop mindsets, and improve student behaviour.

The PAKSA curriculum is useful for honing student intelligence from the non-cognitive aspect. The Prayer aspect would discipline students in religiosity affairs. They are obligated to worship the god(s) 
they believe in and are not permitted to convert to other religion. In terms of attitude, the school tries to instil good behaviour and the importance of religious tolerance. Furthermore, in terms of knowledge, schools provide not only academic knowledge but also non-academic. Each student is also encouraged to have special Skills. It is because this school believes that every child has different intelligence and potential talents. This intelligence is not only measured based on educational value, but also several other non-academic assessments. These non-academic assessments are the benchmark, making sure students not only graduate with a high school diploma but also life skills. In terms of Action, the school tries to implement a balanced curriculum, of which $30 \%$ is for discussing theory and $70 \%$ for field practice. The Action instrument encourages students to apply the knowledge they gained in daily life and learning activities at school.

In implementing PAKSA curriculum, the school sets three main rules that students must follow. First, every student must not insult other religions and maintain mutual religious tolerance. Second, every student prohibited from dating. Third, every student prohibited from listening to mellow songs and is required to read books for self-development. Various curricula and rules are deliberately applied to create an active learning system so that after graduation, students have excellent soft skills and attitude to prepare them to compete in the workforce.

Discipline lesson is beneficial in educational institutions (Marshall 1989), and SPI High Schools can discipline their students to become workers who serve large corporations. It can see from the different, and 'hidden', curriculum. In a school-structured curriculum, students are normalized to become part of business activities, either as new bourgeoisie or as workers. Educational attention centred on internalizing worker values based on the capacity of each student; some students become blue-collared workers, others become white-collared workers. In line with Bowles and Gintis (1976), learning in schools has a significant role in maintaining economic inequality through curricula and social differentiation which then legitimizes that students' failure to achieve success is a matter of lack of talent and lack of competence. Life skill and PAKSA curricula, in this case, discipline students to supply the abilities and values needed by the job market.

Entrepreneurship curriculum has the most significant portion when compared to others in terms of honing students' soft skills to be better prepared when entering the workforce. The development of soft skills is done based on the passion of each student towards a particular division. The selection of divisions in the development of soft skills cannot be made arbitrarily by students, but by the decision of the division senior. A division senior is an SPI High School alumnus who participates in the internship program at the school.

After receiving a variety of entrepreneurship curricula, students can immediately practise the knowledge gained in entrepreneurial laboratories. The laboratory was named Kampoeng Kidz. Kampoeng Kidz is an educational tour which is intended as a medium of learning practice so that students get much experience when they graduate. Based on the results of interviews with several students at SPI High School, they generally have diverse perspectives on the practice of free education at the school. Some students stated that the practice of free education at SPI High School was beneficial to ease the burden on parents and deepen business knowledge. Several other students stated that the practice of free education here is not entirely free because students also actively contribute to helping school finance through the Kampoeng Kidz business.

\footnotetext{
"It is better here. Not only it eases the parents, but students can also learn to do business" (ALY, SPI High School Program Division).

"Here, we usually say, "The school is free for you. Everything is provided. Things that you practice; they all will be useful for you later in the future. All the knowledge you gain here is priceless," that is the version that goes around here (laughs). As for me, I say it is not free. We also produce things" (AY, SPI High School Hydroponics Division).
}

This practice of learning in this school is consistent with free education programs in general. The aim of free education is not just moral goodness to increase APS, but also to support development 
in terms of economic growth (Lucas \& Mbiti 2012, Nkurunziza et al. 2012). An adequate number of workers is needed to realize this, and free education is expected to supply new workers. Furthermore, this result shows that schools organize students learning inside and outside the classroom to support economic infrastructure (Bowles \& Gintis 1976), namely the interests of capital owners. Learning in free schools, similarly, maintains injustice by legitimating that success, and thus failure, is based on personal merit.

\section{Conclusion}

This study aims to identify the structure of free education in capitalist society and then exposes its elements to disentangle the definition of conventional free education. Through a phenomenological study of twenty-one informants involved in a free school, researchers argue that free education, instead of fighting for fundamental rights to achieve justice, maintain injustice by encouraging (or, lowering) lower-class children to be the dominated class (i.e. working class). Free education, regretfully, has yet become a program that frees students from economic, social, and political oppression.

Through this research, three essential elements in free education revealed: 1) false resistance, 2) the formation of economic relations with the dominant class, and 3) the normalization of individuals to support capitalism through the curriculum. First, although free education is considered a moral virtue to provide access for those who cannot go to school, class oppression - the core problem of capitalist society - is not heeded. Second, the dominant class still holds the direction of free education because of the dependence of financial assistance. Finally, free education, corresponding with the capitalist society outside it, structures learning to support and maintain class domination through discipline.

The findings of this study differ from most studies which accept the concept of free education as a good thing: it strives for fundamental human rights, and thus crucial for national development. This study proposes a new definition that free education needs to be understood as a practice that is classbiased and maintains class dominance.

\section{References}

Article 33 Law of the Republic of Indonesia (2016) Pendanaan Pendidikan Dasar Gratis Berkualitas di Indonesia. https://www.neliti.com/id/publications/774/pendanaan-pendidikan-dasargratis-berkualitas-di-indonesia.

Assaad R \& Krafft C (2015) Is free basic education in Egypt a reality or a myth? International Journal of Educational Development 45:16-30. https://doi.org/10.1016/j.ijedudev.2015.09.001.

Ball S (2012) Politics and Policy Making in Education: Explorations in Sociology. Routledge.

Bhattacharya R (2012) Comparative analysis of the extent of free education and average private expenditure on education in India. Procedia-Social and Behavioral Sciences 37:277-295. https://doi.org/10.1016/j.sbspro.2012.03.294.

Bowles S \& Gintis H (1976) Schooling in Capitalist America: Educational Reform and the Contradictions of Economic Life. https://doi.org/10.2307/2062685.

Chyi H \& Zhou B (2014) The effects of tuition reforms on school enrollment in rural China. Economics of Education Review 38:104-123. https://doi.org/10.1016/J.ECONEDUREV.2013.11.003.

d'Aiglepierre R \& Wagner L (2013) Aid and universal primary education. Economics of Education Review 37:95-112. https://doi.org/10.1016/j.econedurev.2013.09.001.

Datzberger S (2018) Why education is not helping the poor: findings from Uganda. World Development 110:124-139. https://doi.org/10.1016/j.worlddev.2018.05.022.

Earle A, Milovantseva N, \& Heymann J (2018) Is free pre-primary education associated with increased primary school completion? A global study. International Journal of Child Care and Education Policy 12 (1):13. https://doi.org/10.1186/s40723-018-0054-1. 
Franks DD (2019) Neurosociology: fundamentals and current findings. In SpringerBriefs in Sociology. https://doi.org/10.1007/978-94-024-1600-8.

Gill MJ (2014) The possibilities of phenomenology for organizational research. Organizational Research Methods 17 (2):118-137. https://doi.org/10.1177/1094428113518348.

Harris K (1994) Teachers Constructing the Future. Falmer Press.

Kalekin-Fishman D (2008) "False consciousness" how "Ideology" emerges from the encounter of body practices and hegemonic ideas. Current Sociology 56 (4):535-553. https://doi. org/10.1177/0011392108090941.

Labaree DF \& Cole M (2006) Bowles and gintis revisited: Correspondence and contradiction in educational theory. Contemporary Sociology 18 (6):950. https://doi.org/10.2307/2074232.

Lesoli MK, van Wuk C, van der Walt JJ, Potgieter FJ, \& Wolhuter CC (2014) The elusive goal of universal free primary education in Africa: The case of Lesotho. Journal of Third World Studies XXXI (2):197-219.

Lincove JA (2009) Determinants of schooling for boys and girls in Nigeria under a policy of free primary education. Economics of Education Review 28 (4):474-484. https://doi. org/10.1016/j.econedurev.2008.10.001.

Lucas AM \& Mbiti IM (2012) Access, sorting, and achievement: the short-run effects of free primary education in Kenya. American Economic Journal: Applied Economics 4 (4):226-253. https:// doi.org/10.1257/app.4.4.226.

Marshall JD (1989) Foucault and education. Australian Journal of Education 33 (2):99-113. https:// doi.org/10.1177/168781408903300201.

Marx K (1932) Economic \& Philosophic Manuscripts of 1844. In Economic and Philosophic Manuscripts of 1844. https://www.marxists.org/archive/marx/works/download/pdf/ Economic-Philosophic-Manuscripts-1844.pdf.

Ministry of National Planning and Development \& UNICEF (2017) SDG Baseline Report on Children in Indonesia. https://www.unicef.org/indonesia/id/SDG_Baseline_report.pdf.

Muyanga M, Olwande J, Mueni E, \& Wambugu S (2010) Free primary education in Kenya: an impact evaluation using propensity score methods. In: J Cockburn \& J Kabubo-Mariara (eds). Child Welfare in Developing Countries (pp. 125-155). https://doi.org/10.1007/978-14419-6275-1_5.

Nkurunziza J, Broekhuis A, \& Hooimeijer P (2012) Free education in Rwanda: just one step towards reducing gender and sibling inequalities. Education Research International:1-11. https://doi. org/10.1155/2012/396019.

Osborne JW (1994) Some similarities and differences among phenomenological and other methods of psychological qualitative research. Canadian Psychology/Psychologie Canadienne 35 (2):167-189. https://doi.org/10.1037/0708-5591.35.2.167.

Shi X (2016) The impact of educational fee reduction reform on school enrolment in rural China. The Journal of Development Studies 52 (12):1791-1809. https://doi.org/10.1080/00220388 .2016 .1156094 .

Supriyadi UD (2010) Pelaksanaan BOS dan minat masyarakat mengikuti pendidikan dasar gratis. Jurnal Ilmu Pendidikan 17 (38):79-85. https://www.neliti.com/id/publications/113022/ pelaksanaan-bos-dan-minat-masyarakat-mengikuti-pendidikan-dasar-gratis.

Thompson MJ (2015) False consciousness reconsidered: a theory of defective social cognition. Critical Sociology 41 (3):449-461. https://doi.org/10.1177/0896920514528817.

Tucker RC (1978) The Marx-Engels Reader (2nd ed.). New York: W. W. Norton. 
UNESCO, UNICEF, Bank TW, UNFPA, UNDP, Women U, \& UNHCR(2015)Education 2030, Incheon Declaration and Framework for Action. World Education Forum 2015, 1-107. http://www. unesco.org/new/fileadmin/MULTIMEDIA/HQ/ED/ED_new/pdf/FFA-ENG-27Oct15.pdf.

Urwick J (2011) "Free Primary Education" in Lesotho and the disadvantages of the highlands. International Journal of Educational Development 31 (3):234-243. https://doi.org/10.1016/j. ijedudev.2010.07.004.

Willis PE (1981) Learning to Labor: How Working Class Kids Get Working Class Jobs. Columbia University Press.

Xiao Y, Li L, \& Zhao L (2017) Education on the cheap: the long-run effects of a free compulsory education reform in rural China. Journal of Comparative Economics 45 (3):544-562. https:// doi.org/10.1016/j.jce.2017.07.003. 